\title{
Saudi Law as Lex Arbitri: Evaluation of Saudi Arbitration Law and Judicial Practice
}

\author{
by ABDULRAHMAN BAAMIR* and ILIAS BANTEKAS**
}

\begin{abstract}
Disputes settled in Saudi Arabia, or which otherwise contain Saudi elements, are governed by the Kingdom's lex arbitri, which requires that not only the arbitration clause and compromis be submitted to a designated competent authority for approval, but that the proceedings be supervised by said competent authority throughout their duration, save where conflict of laws rules permit the parties to refer to a foreign jurisdiction. There is no clear line of authority between contemporary Saudi arbitration law and Hanbali arbitral jurisprudence. Equally, the decisions of the arbitral governing authority (Diwan), although important, does not lend itself formally to stare decisis. Our analysis has demonstrated that this Hanbali corpus of law is in fact more flexible than Saudi law, particularly on the ground of interpretative techniques. This finding should dismiss the notion that Hanbalism is an archaic and backward-looking institution.
\end{abstract}

\section{INTRODUCTION}

UNLIKE OTHER Arab nations, particularly the United Arab Emirates (UAE) and Egypt, which have successfully instilled trust in the minds of foreign and local investors with regard to the settlement of business disputes, as well as the enforcement of foreign arbitral awards therein, the Kingdom of Saudi Arabia has notably failed in both respects. ${ }^{1}$ This is attributable to a number of factors, all of which are unrelated to the contention that arbitration is not favoured in Islamic jurisprudence. To the contrary, the Prophet Mohammed not only admonished the use of arbitration in the field of family disputes, ${ }^{2}$ but also made it his practice

* LLM, DPhil Brunel Law School. Legal Advisor, Baamir Trading \& Real Estate < abdulrahman.baamir@gmail.com>.

** Professor of International Law and Head of International Law and Arbitration, Mourgelas \& Associates Law Firm (Athens). The authors wish to make the following disclaimers. First, all Saudi court judgments mentioned in this article are unreported and the names of parties, as well as the nature of the disputes, are confidential. The texts of the judgments, however, are on file with the authors. Secondly, Saudi Arabia uses the lunar Hejira calendar, whose date of commencement is 622 AD. References in this article are to the Hejira $(\mathrm{H})$ calendar, followed, where appropriate by a reference to the Gregorian calendar.

1 See C.N. Brower and J.K. Sharpe, 'International Arbitration and the Islamic World: the Third Phase' in (2003) 97 AfIL 643, who argue that we are currently experiencing a third phase of business development, in which a great number of Muslim countries are actively participating in the global arbitration movement.

2 Quran, verse 4:35; verse 49:9 is generally cited as exhortation to mediation.

ARBITRATION INTERNATIONAL, Vol. 25, No. 2

(C) LCIA, 2009 
to resort to arbitration where disputes arose between Arab tribes, ${ }^{3}$ or between Muslims and non-Muslims, the latter signified particularly with the signing of the 622 AD Medinah Treaty. It is undeniable that the Islamic legal tradition, and more particularly the teachings of the Hanbali school, has played a significant role in the shaping of the Saudi attitude toward arbitration, ${ }^{4}$ but to argue that Islam necessarily thwarts arbitration is unsustainable because neighbouring Arab countries enjoying the same legal traditions have established themselves as favourable arbitration fora and credible countries of enforcement. Saudi conservatism in the field of arbitration, therefore, may currently be attributed to a series of arbitral awards rendered in the aftermath of the early decolonisation and nationalisation era, in which some arbitrators undermined Islamic law as the applicable law of the relevant contracts on the ground that it was either insufficiently elaborate and therefore unsuitable for settling business disputes ${ }^{5}$ or that it simply could not secure the interests of private parties. ${ }^{6}$ The rejection of Islamic law (as a necessary extension of local laws premised exclusively on the Shari'a) is even more remarkable if one considers that the parties had agreed that Islamic (or Saudi law, where relevant) was in part or in whole the applicable law of the contract. ${ }^{7}$ As a result of the $A R A M C O$ award, the Saudi government adopted Resolution 58, which effectively closed the doors to all government agencies to arbitrate with third entities. ${ }^{8}$

The legal nature of arbitration is itself hotly contested in Islamic jurisprudence. Some scholars are of the view that arbitration is no more than a form of conciliation whose purpose is to make peace between spouses, or, more broadly for our purposes, the contracting parties. ${ }^{9}$ Others believe that arbitration is a mechanism with binding character and in fact this is the prevailing view among

\footnotetext{
Reported in LIAMCO v. Libyan Arab Republic (1981) 62 ILR 140.

4 F.M. Kutty, 'The Sharia Factor in International Commercial Arbitration' in (2006) 28 Loyola LA Int'l and Comp. $L$ Rev. 565 at pp. $567-568$.

5 Petroleum Development (Trucial Coasts) Ltd v. Sheikh of Abu Dhabi (1951) 18 ILR 144, per Lord Asquith at 149; Ruler of Qatar v. Int'l Marine Oil Co. Ltd (1953) 20 ILR 534, per Bucknill J at 545.

6 Kingdom of Saudi Arabia v. ARAMCO (1963) 27 ILR 117 at 169.

7 As a result, the arbitrators viewed the contracts as having been internationalised. See A. Anghie, Imperialism, Sovereignty and the Making of International Law (Cambridge UP, 2005), pp. 225-228.

8 Council of Ministers Resolution No. 58 of 03/02/1383 H (25/06/1963). The ARAMCO arbitration award was one of the early cases concerning the international energy industry and one of the very few cases involving the Saudi government. The dispute occurred as a result of the Onassis agreement between the Government of Saudi Arabia and the Greek-born shipping tycoon. The agreement granted Onassis the right to establish a private company in Saudi Arabia under the commercial name of Saudi Arabian Maritime Tankers Company, which was granted the right of priority for the transport of oil for a period of 30 years. The dispute at issue arose when the government of Saudi Arabia ordered ARAMCO to apply Royal Decree No. 5737 of 9 April 1954 that ratified the Onassis agreement, itself concluded 20 January 1954. The Royal Decree gave the Onassis agreement a legal status similar to that of the ARAMCO Concession Agreement of 1933 which was against the interest of ARAMCO. The parties established an ad hoc arbitration tribunal in 1954 but the final award was issued in 1958. One of the most important outcomes of the final award was the dismissal of the right of the Saudi Arabian Maritime Tankers Company to transport Saudi oil, which ended the short life of that company.

9 See generally, A.M. Al-Kenain, Altahkeem fee asshari'a Alislamiya; Altahkeem Al'am wa Altahkeem ind Asshiqaq Alzaouji [Arbitration in Islamic Shari'a: General Arbitration and Arbitration in Matrimonial Disputes] (Dar Al Asima Lelnashr wa Altaouze' Publishers, 2000).
} 
the Hanbali school, which itself is the dominant Islamic jurisprudence in Saudi Arabia. ${ }^{10}$ In any event, mediation forms a very significant part of popular and legal culture in Saudi Arabia because the judge's first duty is to mediate between the parties before commencing trial proceedings. Equally, specialised commissions under the Ministry of Commerce and Industry, the Ministry of Labour and Social Affairs and the Saudi Monetary Agency, to which disputes are referred, are not judicial bodies and mediation is an essential part of their functions. For instance, Article A of the Royal Decree establishing the Committee for the Settlement of Banking Disputes provides for the formation of a specialised committee with the aim of resolving conflicts with respect to banking disputes in accordance with the contract signed by the parties. ${ }^{11}$ Moreover, there are a number of social factors that render mediation, in some cases, the most appropriate means of settling disputes.

The very limited number of cases in which Saudi public entities are involved in disputes with foreign investors do not usually reach the stage of arbitration. ${ }^{12}$ More recently, the Saudi practice, as reflected in a series of 2004 gas concession agreements, provides for a negotiating period of nine months before any of the parties can refer the dispute to arbitration. These considerations aside, reference to arbitration in business contracts is very common and by no means a rare phenomenon. This article does not examine arbitrations and contracts in which the Saudi government is a party. Rather, it discusses the intricacies of Saudi legislation with respect to disputes referred to arbitration in which at least one of the parties is either a Saudi national, an entity incorporated in Saudi Arabia, or where a Saudi element is somehow involved over which Saudi courts would normally entertain jurisdiction. The article traces all the stages, from the drafting of the arbitral clause to the enforcement of the award, to demonstrate the restrictions imposed therein by Saudi law and the binding supervisory authority of Saudi courts. The authors do not rely solely on the provisions of Saudi arbitral legislation, but instead strive to determine whether and to what degree the relevant Saudi legislation is in conformity with Hanbali teachings pertaining to arbitration, and if the these two sources of law are considered equally by the judicial authorities.

\section{THE SAUDI ARBITRATION ACT AND ITS IMPLEMENTING RULES}

The Arbitration Act of Saudi Arabia was adopted by Royal Decree No. M/46, issued on 12/07/1403 $\mathrm{H}$ (1983), repealing in the process the relevant provisions

10 Quran, verse 4:58. For a discussion of the relevant positions, see Kutty, supra n. 4 at pp. 596-598; on 1/7/1347 $\mathrm{H}$ (1928), the Saudi Judicial Board addressed a resolution to Saudi courts that mandated them to rely on Hanbali jurisprudence when adjudicating secular transactions. N.B. Turck, 'Resolution of Disputes in Saudi Arabia' in (1991) 6 Arab LQ3.

11 Royal Decree No. 729/8 of 10/07/1407 H (1987).

12 Ed. Züblin $A G$ v. Kingdom of Saudi Arabia, ICSID Case No. ARB/03/1. 
of the Commercial Court Code of 1931. ${ }^{13}$ The Implementing Rules of the Act were subsequently adopted by Royal Decree in 1985. ${ }^{14}$ The purpose of the Implementing Rules was to supplement lacunae in the Act and provide guidance on particular aspects of Saudi arbitral proceedings. More specifically, the Act is silent regarding numerous procedural issues, such as the rules pertaining to the delivery of arbitral awards, notifications as to the process and communication between the parties and the arbitral tribunal and between the arbitral tribunal and third parties, the seat of the arbitral tribunal, and others. It will be demonstrated that the Act constitutes a codification of the Hanbali law of arbitration $^{15}$ as elaborated by Ibn Taymiyyah, (1263-1328), in his collection of Fatwas ${ }^{16}$ and Ibn Qudamah (1146-1223), in his comprehensive work Almoghni, which is considered the most authoritative source of Hanbali teachings until the present day. ${ }^{17}$ The Act provides a framework for flexible commercial arbitration with a view to establishing it as a real and effective alternative dispute resolution mechanism. Prior to the adoption of the 1983 Act, arbitration existed only as a theoretical possibility on account of several factors. First, the courts at the time did not recognise arbitration agreements or clauses, even where the parties claimed a contractual entitlement to arbitrate as a result. Even where the court approved the arbitration agreement or clause, the subsequent enforcement of the arbitral award was wholly voluntary. ${ }^{18}$ Accordingly, reference to arbitration was very limited. Secondly, the jurisdictional conflict between the Saudi Commercial Court ${ }^{19}$ and Shari'a courts culminated in rendering arbitration ineffective and time-consuming. Although, the Arbitration Act of 1983 superseded the arbitration provisions of the Commercial Court Code of 1931, ad hoc

13 Reprinted in Umm Alqura Gazette, No. 2969 of 22/08/1403 H (1983).

14 Royal Decree No. M/7/2021, of 08/09/1405 H (1985), reprinted in Umm Alqura Gazette, No. 3069 of $10 /$ 10/1405 H (1985).

15 See generally, S. Saleh, Commercial Arbitration in the Arab Middle East: a Study in Shari'a and Statute Law (Graham and Trotman, 1984). See also, I. Abdal-Haqq, 'Islamic Law: an Overview of Its Origin and Elements' in (2002) 7 f Islamic Law and Culture 28. The Hanbali school was founded by Ahmad bin Muhammad bin Hanbal (780-855 AD), who was a narrator of the Sunnah and a Shafi'e student. The teaching of bin Hanbal is relatively conservative because it is strongly based on the Qur'an and the Sunnah, with a smaller room for Qiyas and other methods of reasoning. See infra n. 148. Although the Hanbalis are strict in religious ritual, they are the most tolerant and flexible in commercial and financial transactions. Hanbalism is the official religious school in Saudi Arabia; it is also widely spread in parts of Syria and some of the Gulf States. In 1927, King Abdul-Aziz Al Saud declared his intention to draft a code embodying the teaching of the Hanbali scholar of the late period, Ibn Taymiyyah. Although this plan was opposed by traditional religious scholars and was eventually shelved, Ibn Taymiyyah's teaching still remains one of the main pillars of the Saudi legal system. Non-Saudis in general use the term Wahhabism when describing the Saudi legal system or the official religious school in Saudi Arabia, which misrepresents the political history of this country.

16 Ibn Taymiyyah, Majmou' Alfatawa [Collection of Fatwas] (Ministry of Islamic Affairs of Saudi Arabia, 1993), vol. 29.

17 Ibn Qodamah Almaqdisi, Almoghni (Hajar Publications, 1992), vol. 10. The term Almoghni is an adjective that has no equivalent in the English language, but an approximate translation could be 'the comprehensive one'.

18 M.N. Albejad, Altahkeem fe Almamlakah Al arabiya Alsaudiya [Arbitration in Saudi Arabia] (Riyadh Institute of Public Administration, 1999), p. 30.

19 Upon its establishment there was only one commercial court seated in Jeddah, which was later substituted by the Commission for the Settlement of Commercial Disputes under the supervision of the Ministry of Commerce and Industry. 
arbitrations lacking a commercial character are still governed by the provisions of the Commercial Court Code. ${ }^{20}$ While one generally speaks of either ad hoc or institutional arbitration, in Saudi Arabia there is yet another classification on the basis of the nature of the dispute as either compulsory or voluntary arbitration. As a general rule, resort to arbitration is voluntary ${ }^{21}$ except where the regulator recommends the compulsory route in a particular case. The rationale behind this classification is to restrict the jurisdiction of the Shari'a courts with respect to some controversial matters under the Shari'a, and also to avoid the conflict between Shari'a and Saudi law, on the one hand, and Saudi law and some customs and traditions, on the other hand. ${ }^{22}$

The Arbitration Act of 1983 is relatively brief and ambiguous in part and, as already stated, lacks detail with respect to some key issues of the arbitration proceedings. Most ambiguous issues were ironed out in the Implementing Rules of 1985. The Implementing Rules are elaborate and highly influential for both arbitral tribunals and the judicial bodies overseeing the arbitral process in Saudi Arabia. The following sections provide an analysis of the Rules with reference to Hanbali arbitration law and the relevant laws in Saudi Arabia, especially the Law of Procedure Before Shari'a Courts. ${ }^{23}$

\section{THE 'COMPETENT AUTHORITIES'}

In accordance with article 1 of the Implementing Rules, arbitration is not permitted with respect to disputes for which conciliation itself is not permitted, such as hodoud, ${ }^{24}$ as well as in all matters relating to public order. As a result, the 1983 Arbitration Act followed the restriction imposed by some Hanbali scholars and rejected arbitrability in criminal matters because they lack a commercial character, and are moreover related to the power of the state. ${ }^{25}$ Hanbali jurisprudence confers upon an arbitrator the same jurisdiction as a court judge. Ibn Taymiyyah did not restrict the scope of arbitration, giving it instead the same authority and function as litigation, save that an arbitral award is of no value without judicial investigation and confirmation. ${ }^{26}$

20 Albejad, supra n. 18 at p. 30.

211983 Arbitration Act, art. 1.

22 Albejad, supra n. 18 at p. 51. Disputes related to tobacco products, insurance, musical instruments and recordings are compulsorily referred to arbitration.

23 As we have already noted, under Hanbali teachings arbitration is equivalent to litigation and the arbitrator is thus analogous to a private judge having specific jurisdiction over the issue at hand only. Article 36 of the Implementing Rules provides that the arbitral tribunal should comply with the litigation principles of the Shari'a. The Implementing Rules were issued in 1985 prior to the enactment of the 2000 Law of Procedure Before Shari'a Courts. Prior to the enactment of the 2000 Law, arbitrators relied on Shari'a principles in order to find governing rules for arbitral proceedings.

24 Hodoud are crimes for which the Quran provides corporal punishment, such as theft, adultery and accusation of adultery.

25 Ibn Qodamah, supra n. 17 at vol. 11, p. 484.

26 A.A.M. bin Mofleh, Al-Forou [The Branches] (A'alam Alkotoub Publishers, 1985), vol. 6, p. 440. 
The capacity of parties to refer a matter to arbitration requires full legal capacity with respect to age and state of mind. ${ }^{27}$ The guardian of a minor, an appointed guardian or trustee of a charitable trust, or what is so-called in Arabic waqf, cannot conclude arbitration agreements unless authorised by the court. ${ }^{28}$ An arbitral award against the guardian of an incapacitated person is invalid if it harms the interests of that person, unless approved by a court. ${ }^{29}$ In accordance with article 5 of the Arbitration Act, the arbitration agreement must be submitted for approval to the competent authority responsible for the subject matter of the dispute. ${ }^{30}$ Within its remit of review of arbitration agreements, the competent authority definitively decides on the existence of possible contradictions with Saudi substantive and procedural law, as well as any violation of public policy. The only three competent authorities are the Diwan Alamzalim (Board of Grievances), the Ministry of Commerce and the Chambers of Commerce and Industry. A fourth authority exists, the Committee for the Settlement of Banking Disputes, whose jurisdiction and powers are exceptional, however, and only in relation to banking disputes. The authority of this entity will be analysed separately in a following section. Upon approval of the arbitration agreement, the competent authority is under an obligation to inform the arbitral tribunal of its decision and subsequently advise it to proceed to the merits of the dispute at issue. If any of the parties refuses to arbitrate after concluding a binding, and approved, arbitration clause, the other party may compose the compromis unilaterally, but always under the supervision of the competent authority. ${ }^{31}$ Where the arbitration agreement (or clause) satisfies all the requirements for approval but remains contested by one of the parties, the competent authority will inform the arbitral tribunal of its approval and ask it to proceed as normal. ${ }^{32}$ Let us now examine the legal nature and status of the three afore-mentioned competent authorities.

The Board of Grievances, Diwan Almazalim, was created in 1955 as a department of the Council of Ministers, Majlis Al Wuzara'. ${ }^{33}$ The Board was later reconstituted as an independent entity. ${ }^{34}$ At first the Board served as a general clearing-house for complaints of a general nature, but it has since evolved into the most important administrative and judicial entity outside the Shari'a courts. ${ }^{35}$ Some authors have argued that the Diwan Almazalim is a sort of Conseil d'Etat, ${ }^{36}$ and was itself transplanted from the Egyptian legal system, which in turn was premised on the Code of Napoleon. However, the principle

271985 Implementing Rules, art. 2. See M. Zahraa, 'The Legal Capacity of Women in Islamic Law' in (1996) 11 Arab LQ245.

281985 Implementing Rules, art. 2.

29 Al-Kenain, supra n. 9 at p. 37.

30 Arbitration Act, art. 5, and Diwan Almazalim, Decision No. 59/T/4 of 1412 H (1992).

31 Diwan Almazalim, Decision No. 184/T/4 of 1412 H (1992).

32 See Diwan Alamzalim, Decision No. 150/T/4 of 1413 H (1993).

33 Royal Decree No. 02/13/8759 of 1374 H (1955).

34 Royal Decree No. (M/51) of $1402 \mathrm{H}$ (1982).

35 G. Sfeir, 'The Saudi Approach to Law Reform' in (1988) 36 Am. 7 Comp. L 729.

36 Ibid. 
of Qadi Almazalim is well known in Shari'a treatises many centuries prior to the promulgation of Napoleonic laws. ${ }^{37}$ Upon its establishment, the Diwan Almazalim's competence was limited to receiving and investigating complaints in cases where the government or a governmental entity was a party to a dispute. ${ }^{38}$ Due to the rapid economic growth following the oil boom in the 1970s and the trend to reduce the load of Shari'a courts (as well as a desire to found a specialised legal body for settling commercial matters where the application of strict Shari'a rules was viewed as an impediment to the flow of foreign investment), the settlement of commercial and investment disputes was conveniently added to the competence of the Diwan. ${ }^{39}$ The Resolution granting the Diwan its additional competence of settling commercial disputes expressly provided, however, that this was a temporary measure until such time as independent commercial courts came into existence or were reconstituted. ${ }^{40}$ Prior to Resolution 261, the Diwan was given the power to consider applications for the execution of foreign judgments and foreign arbitral awards where questions of public policy were at issue. ${ }^{41}$ The effect of a new Resolution that was adopted in September 2007 was to remove some of the Diwan's usual competencies as a commercial court and transfer them to the Ministry of Justice. However, for the purposes of our discussion, the supervision of arbitral proceedings is still under its jurisdiction and according to the new Resolution, the process will take at least two years before the new commercial courts are able to start functioning. The new Resolution also provides for moving the Review Committee for Commercial Matters to the proposed Court of Appeal. ${ }^{42}$ In the meantime, the Diwan's competence remains unchanged.

The Committee for the Settlement of Commercial Disputes was established in 1967 and superseded the Commercial Court established by the Commercial Court Code of 1931. The Committee functioned under the supervision of the Ministry of Commerce and Industry and assumeed jurisdiction over all disputes involving the Kingdom's commercial codes and regulations. The Committee had the authority to settle all disputes arising under the Company Code, Services Agency Code, Commercial Agency Code, as well as all disputes concerning commercial land and maritime issues. Moreover, the Committee was empowered to liquidate companies and impose penalties. Prior to the enactment of the

37 See generally, M. Hanson, 'The Influence of French Law on the Legal Development of Saudi Arabia' in (1987) 2 Arab LQ 272.

38 Ibid.

39 The Diwan comprises five distinct divisions, which may be classified in accordance with their respective jurisdiction into administrative and commercial divisions. The decision of any of these bodies or branches is final and enforceable, unless an appeal is lodged. In the case of appeal (which may concern both questions of fact and law), this may be brought before the Review Committee of the Diwan, or what is known as Hay'at Altadqeeq. The decisions of the Review Committee are final and not subject to any further appeal.

40 Council of Ministers Resolution No. 261 of 17/11/1423 H (2004).

41 See K.T. Roy, 'The New York Convention and Saudi Arabia: Can a Country Use the Public Policy Defence to Refuse Enforcement of Non-Domestic Arbitral Awards?' in (1995) 18 Fordham Int'l Lf 920 at p. 922.

42 Regulation on Amendment to the Diwan Almazalim, reprinted in Umm Alqura Gazette, No. 4170 of 30/09/ $1428 \mathrm{H}(21 / 09 / 2007)$. 
Arbitration Act of 1983, the Committee was the principal supervisory body for supervising arbitral proceedings. ${ }^{43}$ The Committee was composed of three branches that sat in Jeddah, Riyadh and Dammam. Each branch was composed of three full-time members, of whom two were trained in Shari'a law and nominated by the Ministry of Justice, while the third was a legal consultant trained in Saudi law and nominated by the Ministry of Justice. The Committee applied the Shari'a law of procedure and evidence and the commercial codes and royal decrees as substantive law. However, it may validly be claimed that the Regulations applied by the Committee were out of date in many respects, given that most of them were adopted prior to the 1980s and have not since been subject to modifying improvements and modernisation. ${ }^{44}$

After the enactment of the new regulations, this Committee no longer exists and reference to it is made here to give the reader an understanding of the way in which the newly formed commercial courts were established as a successor to the Committee for the Settlement of Commercial Disputes and the commercial department of the Diwan Almazalim.

The role of the Chamber of Commerce and Industry as a competent authority is regulated by article 5 of the Chamber of Commerce and Industry Regulation. According to this, the Chambers are competent to resolve business disputes by arbitration if the parties so agree. ${ }^{45}$ There is little other in Saudi legislation on the nature and functions of the Chambers. It has been noted that the Chamber of Commerce and Industry is not a popular supervisory body of arbitration in Saudi Arabia. Moreover, the Chamber is not the ideal supervisor of arbitral proceedings for the reason that the Chamber itself is not a judicial or a semi-judicial body. The Chamber mainly focuses on ad hoc arbitrations under the UNCITRAL Rules and enjoys no popularity in Saudi Arabia because its function depends heavily on the good faith of the parties to the dispute.

\section{(a) Supervisory Role of the Arbitration Clause and Compromis by the Competent Authorities}

Article 7 of the Implementing Rules deals with the role of the supervisory authority vis-à-vis the arbitral proceedings. The supervisory authority is the authority initially endowed with jurisdiction over the dispute as a whole, including the question as to whether the dispute is subject to arbitration through an arbitration agreement or clause, in the first place. This entity is obligated to issue a decision approving the arbitration agreement within 15 days of submission

43 Commercial Court Code, arts. 493-497; Royal Decree No. 23 of 15/01/1350 H (1931), reprinted in Umm Alqura Gazette, No. 347 of 22/03/1350 H (1931).

44 To file a claim before the Committee, the claim must be directed either to the regional governor or the Minister of Commerce and Industry, who will then refer it to the Committee. The decisions of the Committee are final and enforceable; however, when the prevailing party seeks to enforce the decision, the Committee will notify the regional governor that the decision is final and the governor will supervise its execution. Appeals may be lodged within 15 days of the date of the issuance of the final decision. Commercial Court Code, arts. 459, 531 and 543.

45 Royal Decree No. (M/6) of 60/04/1400 H (1980). 
of the agreement and must thereafter notify the arbitral tribunal of its decision. ${ }^{46}$ Article 7, thus, codifies the teaching of Ibn Taymiyyah who considered the arbitral award to be of no value without prior judicial confirmation. ${ }^{47}$ The existence of multiple competent authorities for the settlement of commercial disputes might seem problematic; however, it should be stated that the Diwan Almazalim has supremacy over the Committee for the Settlement of Commercial Disputes of the Ministry of Commerce and Industry. Regardless of the very recent change in the Charter of the Diwan Almazalim, which had the effect of ceding the competence of settling commercial disputes to the Ministry of Justice, the supervision of arbitral proceedings continues to remain within the Diwan's competences. ${ }^{48}$ As a general rule, the parties are bound by the Arbitration Act and Implementing Rules at all stages of the process and as a result if any agreement or action concluded therein is in conflict with this legislation it will be deemed null and void. The Diwan in its decision 53/T/4 of $1414 \mathrm{H}$ (1994) nullified an arbitral award made without the supervision and approval of the competent authority. In that case, the parties agreed to arbitrate under the supervision of an entity other than the competent authority originally having jurisdiction over the dispute. The Review Committee of the Diwan set aside the award on the afore-mentioned grounds. As a result, the appointment of legal or natural persons as supervisors of arbitral proceedings in the Kingdom, other than the competent authority, constitutes a ground for nullity. ${ }^{49}$ In another case, the Diwan nullified an arbitral award rendered without an approved arbitration agreement. There, the Diwan directed the arbitral tribunal to proceed in deciding the case even though the arbitration agreement had not been approved by the Diwan. The arbitral tribunal proceeded with the process by relying on its communication with the Diwan, which included all the mandatory information; nonetheless, although it was acknowledged that the Diwan was at fault for having failed to inform the arbitral tribunal as to the requirement of confirmation of the compromis, the award was considered null and void because it breached the relevant legislation. ${ }^{50}$

There is a dispute whether the competent authority exercises supremacy over arbitral proceedings even in those cases where the tribunal is seated abroad. A literal interpretation of article 18 of the Arbitration Act ${ }^{51}$ may be understood as providing the supervisory authority with the power to act as an appellate body. However, case law clearly regards the supervisory authority as a lower court and the arbitral tribunal as supreme under such circumstances. Consequently, the Diwan will not have the power to supervise arbitral proceedings taking place

46 Implementing Rules, art. 7.

$47 \mathrm{Al}$ Kenain, supra n. 9 at p. 49.

48 Reprinted in Umm Alqura Gazette, No. 4170 of 30/09/1428 H (12/10/2007).

49 Diwan Almazalim, Decision No. 61/T/4 of 1415 H (1995).

50 Diwan Almazalim, Decision No. 99/T/4 of 1414 H (1994).

51 Arbitration Act, art. 18 reads as follows: 'All awards passed by the arbitrators, even though issued under an investigation procedure, shall be filed within five days with the authority originally competent to hear the dispute and the parties notified with copies thereof. Parties may submit their objections against what is issued by arbitrators to the authority with which the award is filed, within fifteen days from the date they are notified of the arbitrators' awards; otherwise such awards shall be final'. 
abroad and the appropriate lex arbitri under such circumstances will remain the law of the seat state. It is thus evident that Saudi legislators did not wish to frustrate arbitral proceedings held abroad, even when there was a Saudi element in the case, and have refused to impose Saudi lex arbitri to such cases. In case 53/ $\mathrm{T} / 4$ of $1415 \mathrm{H}$ (1995), the Committee stated that:

because the term 'competent authority' in the Arbitration Act and Implementing Rules does not specify the degree of the court, the supervisory authority should apply its own rules of procedure. With regard to the Diwan, we consider it a second degree court after the arbitration tribunal; therefore, the Diwan should apply its own rules of procedure and the Diwan's duty is to uphold or reject the decision of the arbitration tribunal only. ${ }^{52}$

Therefore, the weight of evidence suggests that where the seat of the arbitral tribunal is outside Saudi Arabia, the competent authority's usual power of confirming the compatibility of the compromis with Saudi law is inapplicable.

Finally, although state-investor arbitration is not within the purview of this article, some mention is warranted in terms of explaining whether a degree of confirmation is required thereto. The long-lasting negative impact on the Saudi psyche from the $A R A M C O$ arbitration is reflected in article 8 of the Implementing Rules and article 3 of the Arbitration Act, following from the dramatic Council of Ministers Resolution No. 58 of $1963^{53}$ (adopted in the immediate aftermath of the award), and the Deputy Minister of Commerce's Circular No. 3/9/sh/331/ 9/2903 of 13/03/1399 H (1979). ${ }^{54}$ These legal instruments make it clear that with respect to arbitral disputes to which a government entity is a party, the latter shall prepare a memorandum about the arbitral process and include therein the subject of the dispute, the justification for arbitration and the names of the parties. This memorandum is to be submitted to the President of the Council of Ministers in order for it to consider approval of the arbitration agreement. Some governmental entities are allowed to insert arbitration clauses in their contracts with private parties, but in all cases the Council of Ministers should be notified of the award rendered in relation to such disputes. ${ }^{55}$ In practice, if a governmental entity wishes to resort to arbitration for the settlement of a dispute with a third party, it is obliged to first obtain approval from the President of the Council of

52 Diwan Almazalim, Decision No. 53/T/4 of 1415 H (1995).

53 See supra n. 8.

54 The Ministry of Commerce Companies Circular No. 31/1/331/91 of 1979 confirmed the Council of Ministers' Resolution No. 58 of 1963 in prohibiting or restricting international arbitration. The Circular stated that contractual clauses providing for arbitration (outside the Kingdom) and included in the articles of association of Saudi companies will be considered void. Moreover, articles of association containing such clauses will not be approved or registered. As a result, reference can only be made to domestic arbitration in the articles of association of a joint company that is formed by foreign and local businessmen for the purpose of carrying out investment operations in Saudi Arabia. This restriction includes all types of joint companies, whether formed by foreign investors and a private Saudi party, or by foreign investors and the government of Saudi Arabia. See Y. Al-Samaan, 'The Settlement of Foreign Investment Disputes by Means of Domestic Arbitration in Saudi Arabia' in (1994) 9 Arab LQ217 at pp. 217-220, and Y. Al-Samaan, The Legal Protection of Foreign Investment in the Kingdom of Saudi Arabia (Dar Al Andalus Publications, 2000), pp. 243-244.

55 Implementing Rules, art. 8. 
Ministers; however, a governmental entity may incorporate an arbitration clause in its contracts without approval from the President. ${ }^{56}$

\section{(b) Committee for the Settlement of Banking Disputes}

The Committee for the Settlement of Banking Disputes was established under the aegis of the Saudi Arabian Monetary Authority (SAMA) with the aim of settling disputes between banks and their clients, where these arise from contracts and transactions that are unrelated to commercial guarantees, such as bills of exchange and letters of credit, jurisdiction over which is vested in the other three competent authorities. ${ }^{57}$ According to the Royal Decree establishing the Committee, banking disputes may no longer be referred to Shari'a courts or the Commission for the Settlement of Commercial Disputes, unless otherwise expressly authorised, but instead should be referred to the Committee. The new Committee has been granted a wide field of discretion by its founding decree. ${ }^{58}$ In order to enhance the authority and functions of the Committee, the Minister of Justice officially informed all Shari'a courts about the Committee's exclusive rights and instructed them under strict terms to cease entertaining banking disputes. ${ }^{59}$ The Committee's competence in hearing banking disputes is exclusive. Disputes of this nature exist where at least one of the parties is a bank and the subject matter of the dispute relates to a banking operation. ${ }^{60}$ As provided in article 10 of the Regulation of Internal Procedures and Rules for the Function of the Committee, the parties may agree to refer their dispute to arbitration, either as an arbitration clause in their main contract after a dispute has arisen, or even during the procedure before the Committee. Thus, the option of arbitration is not precluded on the grounds of the Committee's exclusive competence. As arbitration clauses are considered to be valid, the question arises whether the Committee can act as a supervisory authority over arbitral proceedings under the Arbitration Act of 1983, in the same manner as the Diwan and the other two afore-mentioned entities. The Arbitration Act provides that the competent authority possesses a supervisory role over all stages of the arbitral proceedings. On the one hand, the Committee is the competent body for settling banking disputes, but on the other hand, the Committee's Regulation of Internal Procedures and Rules points out that the Committee is not in actual fact a court

56 For further details, see Appendix Z of the 2004 Gas Concession Agreement between the Kingdom of Saudi Arabia and Lukoil Overseas Corp. and the 2004 Gas Concession Agreement with Sinopec Int'l Petroleum \& Production Corp, reprinted in Umm Alqura Gazette, No. 3990 of 15/03/1425 H (4/05/2004).

57 Royal Decree No. 729/8 of 10/07/1407 H (1987).

58 See R. Meyer-Reumann, 'The Banking System in Saudi Arabia' in (1995) 10 Arab LQ207.

59 Circular of the Minister of Justice No. 732/8 of 10/07/1407 H (1987), which informed all Shari'a court judges of the exclusive jurisdiction of the Committee for the Settlement of Banking Disputes over disputes arising out of banking activities.

60 Banking business (or activities) has been defined in Banking Control Law of 1966, art 1.b, as the business of receiving money on current or fixed deposit accounts, opening of current accounts, opening of letters of credit, issuance of letters of guarantee, payment and collection of cheques, payment orders, promissory notes and equivalent exchanges of value, discounting of bills of exchange and other commercial papers, foreign exchange transactions and other banking business. 
in the sense of Shari'a courts, nor a judicial body like the Diwan Almazalim. ${ }^{61}$ The Regulation enables the Committee to refer disputes which it cannot itself determine to the competent court that would normally exercise jurisdiction had the dispute in question not been a banking one. This necessarily means that the Committee cannot be classified as a 'competent authority' for the purposes of the Arbitration Act and is, therefore, not endowed with the authority to supervise arbitration proceedings. In reality, the Committee is not a fully competent authority to settle banking disputes and most disputes of this nature are referred to a very large degree to the Diwan Almazalim in its capacity as a competent authority that supervises arbitration proceedings and reviews and enforces arbitral awards. ${ }^{62}$

The enforcement of the Committee's decisions is severely obstructed since the Regulation does not explicitly provide which entity is responsible for enforcing its decisions and how this is to take place. The remedies available before the Committee include the freezing of the debtor's assets, entitlements or funds held by Saudi governmental agencies, or preventing the debtor from travelling outside the Kingdom. ${ }^{63}$ Moreover, the Committee possesses the authority to prevent a debtor from conducting any further business with the government, governmental entities or even banks if said person did not participate in the settlement procedure and blocked any positive solutions. The Committee's jurisdiction encompasses also those cases involving claims of a debtor of a bank against the government or a governmental agency.

\section{LEGAL NATURE OF THE COMPROMIS UNDER SAUDI LAW AND HANBALI TEACHINGS}

It is within the purview of the competent authority to recognise the legal validity of the arbitration agreement or clause. Article 6 of the Implementing Rules overcomes one of the main impediments to arbitration in Saudi Arabia which is the recognition of the arbitration clause. Prior to the Arbitration Act, the Shari'a courts did not recognise arbitration clauses as valid contracts under Islamic law, deeming them to constitute speculative contracts or conditions. They did, however, recognise compromis as valid contracts on the basis that they were not speculative as a dispute was actually present, in contrast to arbitration clauses. Article 6 specifies the minimum amount of information that must be inserted in the agreement. This includes a contractual undertaking by which the parties agree to the appointment of arbitrators, further adequately defining the subject matter and scope of the dispute and the names of the arbitrators. This obviously relates to a compromis. An agreement to arbitrate may also be made through an arbitration clause relating to disputes arising out of the main contract. ${ }^{64}$

\footnotetext{
61 See generally, Albejad, supra n. 18.

62 Meyer-Reumann, supra n. 58.

63 Ibid.

64 Implementing Rules, art. 6.
} 
The failure of courts to recognise arbitration clauses was a striking feature of judicial practice under the Commercial Court Code of 1931, rendering arbitration an impractical and time-consuming dispute settlement mechanism. ${ }^{65}$ The norm was for courts to reject the validity of arbitration clauses because judges doubted their compatibility with Shari'a, deeming them to encompass a degree of uncertainty as to the parties' dispute. The rationale is astonishing to a non-Muslim lawyer, but it is perfectly logical under the prescriptions of Shari'a. Whereas a condition for the validity of an arbitration agreement is the existence of a dispute, where a dispute is stipulated in terms of a future event, strictly speaking the arbitration clause may be said to exist in a factual vacuum. Although this has never been an issue under Western contract law (and, in fact, insurance law, among others, is premised on future events), under Shari'a, a contract whose object does not exist at the time of its conclusion is invalid and is similar to a class of prohibited contracts, such as the selling of fish in the sea or birds in the sky. 66 On the contrary, Hanbali teaching, being the most flexible Islamic school in the field of commercial transactions, has always considered arbitration clauses as possessing a valid contractual nature, insofar as they are not in conflict with the purpose of the contract and not prohibited under the Shari'a. ${ }^{67}$ The rejection of arbitration clauses in Islamic jurisprudence, therefore, has arisen as a result of the judges' misunderstanding of the contractual nature of such clauses.

Traditionally, a compromis under Islamic law requires the names of the arbitrators, the subject matter of the dispute, applicable law, the dates of the proceedings, as well as the seat of the arbitration. ${ }^{68}$ These requirements have been historically associated with the famous incident of Tahkeem, between Ali, the fourth Caliph and Mu'awiyah, the governor of Syria, in the year 659 AD. A civil war had erupted as a result of the assassination of the third Islamic Caliph, Othman, which lasted for more than two years. With a view to ending the civil conflict, the dispute was submitted to arbitration by means of a written agreement, whereby the two parties agreed to appoint two named arbitrators, a provision on the time limit for rendering the award, the applicable law and the place where the award was to be made. ${ }^{69}$ The same legal tradition was subsequently followed in the arbitration agreements between Saudi Arabia and ARAMCO, as well as that between Saudi Arabia, Abu Dhabi and Oman in the 1950s. ${ }^{70}$ Under Saudi arbitration law, there is no need to determine the applicable law in the compromis or the arbitration clause because this will always

65 See Albejad, supra n. 18 at p. 30.

66 See generally, N. Saleh, 'The Law Governing Contracts in Arabia' in (1989) 38 ICLQ 761; S.E. Rayner, The Theory of Contracts in Islamic Law (Kluwer, 1991).

67 See generally, Ibn Qudamah, supra n. 17 at vol. 14.

68 G. Sayen, 'Arbitration, Conciliation and the Islamic Legal Tradition in Saudi Arabia' in (1987) 9 U Penn $\mathcal{J}$ Int'l Business L 211.

69 Z. Alqurashi, 'Arbitration under the Islamic Shari'a' in (2003) 1 OGEL (March).

70 ARAMCO Award, supra n. 6 at p. 128. See also, Arbitration Agreement between the Government of the United Kingdom acting on behalf of the ruler of Abu Dhabi and His Highness the Sultan Said bin Taimur, the Sultan of Oman, and the Government of Saudi Arabia, signed in Jeddah on 30 July 1954 (Cmd. 9272, 1954), cited in J.B. Kelly, 'The Buraimi Oasis Dispute' in (1956) 32 International Affairs 318. 
be by default the Shari'a or Saudi law. This was, indeed, taken for granted in the Tahkeem arbitration and has not subsequently been disputed in Islamic legal scholarship. Moreover, Hanbali teachings grant the parties unrestricted freedom to incorporate any other condition in their arbitration agreement, even if irrelevant to their dispute, provided that it is not contrary to Shari'a principles. $^{71}$

Under Saudi law, the existence of the arbitration clause does not affect the right of the parties to resort to litigation. Case law demonstrates that referral of a dispute to litigation in the presence of an arbitration clause constitutes an implied waiver of the parties' right to arbitrate. In decision 29/T/4 of $1413 \mathrm{H}$ (1993), the Diwan emphasised the parties' right to insist on the recognition of arbitration as a valid contractual undertaking for settling their disputes. ${ }^{72}$ For a while it was thought that referring a dispute to litigation entails a waiver of the parties' right to arbitrate, whereupon the arbitration clause ceases to have any legal effects. ${ }^{73}$ Although this view was initially supported by decision 72/T/4 of $1411 \mathrm{H}$ (1991), with which the Diwan rejected referral to arbitration where one of the parties was opposed to arbitration, the Review Committee of the Diwan was of an opposite view. It held that referring a dispute to litigation while an arbitration agreement is in existence, does not extinguish the parties' right to refer their dispute to arbitration. Subsequently, the Committee confirmed the nullification of the arbitration clause because the defendant raised his claim after referring the dispute to litigation. ${ }^{74}$ The precise time when the right to arbitrate is waived by referring the dispute to litigation is yet to be clearly determined, although it is reasonable to suggest that it corresponds with the moment in time at which the dispute is submitted to the Shari'a courts or the Diwan.

It is not of concern to Saudi public policy that the arbitration clause has the effect of waiving the parties' right to refer their dispute to litigation. If one of the parties insists on his right to arbitrate, his claim should be submitted before referring the dispute to litigation, as is clear from Diwan decisions 95/T/4 of $1413 \mathrm{H}$ (1993) and 142/T/4 of $1409 \mathrm{H}$ (1989). ${ }^{75}$ In the latter decision, the Review Committee of the Diwan emphasised that the parties have the right to refer their dispute to litigation even if they have a valid arbitration clause, since litigation is the primary method for settling disputes and arbitration is an exception, which itself has no bearing on public policy. ${ }^{76}$ On the other hand, referral to litigation does not affect the parties' entitlement to arbitration. In case $27 / \mathrm{T} / 4$ of $1411 \mathrm{H}$ (1991), the defendant argued that the plaintiff sued him before a court in the United States and that, therefore, that party had lost its right to resort to arbitration. The Committee determined that the initial referral to litigation did not affect the parties' right to arbitrate. ${ }^{77}$ It is evident that the case

\footnotetext{
Sayen, supra n. 68 at p. 220.

Diwan Almazalim, Decisions Nos. 113/T/4 of 1416 H (1996) and 38/T/4 of 1409 H (1989).

Diwan Almazalim, Decision No. 29/T/4 of 1413 H (1993).

Diwan Almazalim, Decision No. 72/T/4 of 1411 H (1991).

75 Diwan Almazalim, Decision No. 95/T/4 of $1413 \mathrm{H}$ (1993) and 142/T/4 of $1409 \mathrm{H}$ (1989).

76 Ibid. Decision 142/T/4.

77 Diwan Almazalim, Decision No. 27/T/4 of 1411 H (1991).
} 
law is somewhat contradictory and it remains unclear whether referral of the dispute to litigation has the potential of annulling the arbitration clause, or whether said clause remains valid. It should be noted that, unlike common law and civil law practice where judicial precedent plays a significant role in subsequent judgments, Islamic courts are not generally bound by principles of stare decisis. Instead, Islamic courts rely principally on each individual judge or arbitrator's reasoning and understanding. ${ }^{78}$ Thus, judicial determination is, to a large degree, personal and as a result produces significant legal uncertainty.

\section{LEX ARBITRI AND THE SIGNIFICANCE OF THE STATUS OF THE ARBITRATOR}

Unlike arbitration statutes in non-Muslim countries, Muslim nations have historically required that arbitrators determining cases wherein at least one party is Muslim be themselves Muslim. Islamic law is clear on the prohibition of nonMuslims acting as arbitrators and there is general consensus among scholars that non-Muslims are not allowed to adjudicate any dispute involving a Muslim element within Muslim territory. This position is premised on the assumption that arbitration is simply another form of litigation. ${ }^{79}$ The rationale was that since the substantive law of the agreement would by necessity be Islamic law, only a Muslim versed in it would be competent to interpret and apply it. ${ }^{80}$ The Saudi Implementing Rules have not departed from this tradition. ${ }^{81}$ The arbitrator must be a Muslim male of Saudi nationality or a Muslim male of any other nationality practising a liberal profession, or otherwise be a public official endowed with government approval to undertake the role of arbitrator. If there is more than one arbitrator, the chairman should be knowledgeable in Shari'a rules, commercial regulations, as well as the customs and traditions in effect in the Kingdom. ${ }^{82}$ The appointment of sole arbitrators, as well as the validity of arbitral awards rendered by sole arbitrators, has been confirmed through continuous practice as well as by the decisions of the Diwan. ${ }^{83}$

If the arbitration agreement provides for the settlement of the dispute by conciliation, then the arbitrators/conciliators do not have to be Muslims because this type of agreement is considered an agency contract under Hanbali jurisprudence, which non-Muslims are permitted to execute. ${ }^{84}$ Residing in Saudi Arabia is not a condition for the validity of the appointment of the arbitrators. The Arbitration Act is silent on the issue of the place of residence of the

78 N.J. Coulson, A History of Islamic Law (Edinburgh University Press, 1964), pp. 29-35.

79 M.H. Al-Fagy (ed.), Al-Ahkam Al-Sultaniyah [Royal Decisions], (Dar Alkotoub Alilmiyah Publishers, 1983), p. 61.

80 Nonetheless, UAE Civil Procedure Code, art. 206(1) does not require that the arbitrator be Muslim and/or male.

81 Implementing Rules, art. 3.

82 Ibid.

83 Diwan Almazalim, Decision No. 7/T/4 of 1419 H (1999).

84 Ibn Qodamah, supra n. 17 at vol. 14, p. 170. 
arbitrator and requires them simply to be Muslim males. In case 22/T/4 of 1413 $\mathrm{H}$ (1993), the Diwan Almazalim quashed the decision of the Committee for the Settlement of Commercial Dispute which annulled the appointment of an arbitrator on the ground that although a Muslim, he was not a resident of Saudi Arabia. The Review Committee of the Diwan added that such an additional requirement imposed an unnecessary restriction. ${ }^{85}$

Further restrictions are imposed on the appointment of the arbitrators in respect of impartiality, independence and credibility. According to article 4 of the Implementing Rules, the following persons are excluded: those with an interest in the dispute; those convicted of a hadd (single of hodoud), or penalty relating to a crime of dishonour; and those dismissed form public office by punitive decision or court-based bankruptcy, unless relieved therefrom. The same restrictions may be employed to challenge witnesses and evidence adduced as a result. The appointment of an arbitrator possessing any of these traits violates the principle that the arbitrator must be an adl. ${ }^{86}$ The appointment of a fasiq (i.e. someone guilty of openly and flagrantly violating Islamic law and/or someone whose moral character is corrupt) is void because arbitration under Hanbali teachings is tantamount to litigation and therefore the arbitrator should possess all the characteristics of a court judge. ${ }^{87}$

Article 5 of the Implementing Rules obliges the competent authorities to issue an official updated list of all licensed arbitrators; the list should be prepared by agreement between the Minister of Justice, the Minister of Commerce and Industry and the Chairman of the Board of Grievances. The courts, judicial commissions and Chambers of Commerce and Industry are notified of the list and disputants are at liberty to choose arbitrators from this list. The Ministry of Justice requires simply that prospective arbitrators pass an exam before qualifying. The exam is generally composed of a range of topics, such as the mandatory rules of Shari'a and the arbitration procedure under the Arbitration Act and its Implementing Rules, in addition to the laws and customs concerning the particular field in which the arbitrator intends to practice. ${ }^{88}$ The test itself consists of a mere multiple-choice questionnaire that numbers 20 questions. The candidate may download it from the website of the Ministry and submit his responses by fax or post. Given that the questionnaire does not cover a series of important issues, such as public policy, rendering of awards, and rules of procedure, inter alia, it is obvious that the entire process not only lacks transparency, but moreover tolerates and sustains incompetence. ${ }^{89}$ Not surprisingly, the credibility of such a procedure

85 Diwan Almazalim, Decision No. 22/T/4 of 1412 H (1992).

86 Saleh, supra n. 15 at p. 36. Generally, the term adl refers to a person who does not violate Shari'a law and possesses decent mental abilities.

87 Al-Kenain, supra n. 9 at pp. 77-79.

88 See Implementing Rules, art. 5. The list of arbitrators is available on the website of the Ministry of Justice. Available at www.moj.gov.sa/mojcontents.aspx?cms_id=84.

89 In recent years, some exam questions have asked candidates to identify article numbers within the Arbitration Act and the Implementing Rules, the date of ratification of the 1958 New York Convention, as well as explain what the initials of UNCITRAL stand for! 
is disputed even in Saudi Arabia, because anyone can answer the questionnaire for the candidate. Astonishingly, according to the website of the Ministry of Justice, if a candidate fails in answering a question, he can attend an interview, which may consist of a mere repetition of the initial questionnaire. ${ }^{90}$

\section{ROLE OF THE GOVERNING LAW OF THE ARBITRATION GLAUSE FOR THE DETERMINATION OF THE TRIBUNAL'S SEAT}

If the arbitration agreement provides for the settlement of the dispute by means of arbitration outside Saudi Arabia, the agreement is valid only where the conflict of laws rules so permit and one of the parties to the arbitration is not a Saudi national. In decision $155 / \mathrm{T} / 4$ of $1415 \mathrm{H}$ (1995), in which the defendant, a foreign company, requested that arbitration should be held outside Saudi Arabia, the Committee decided that the defendant was bound by the Saudi law of arbitration, ordering therefore that the arbitral tribunal be seated in Saudi Arabia, apply Saudi substantive law on the merits of the dispute, and be supervised by the Diwan Almazalim. ${ }^{91}$ It is crucial to emphasise, however, that were a different law to apply with regard to the merits of the dispute, the Diwan would not oppose arbitral proceedings conducted outside the territory of Saudi Arabia, as was the case in decision 43/T/4 of $1416 \mathrm{H}$ (1996). There, the parties to the dispute, a Saudi and a US corporation, entered into a distribution agreement that contained an arbitration clause stipulating that future disputes were to be referred to the US State of Iowa. The Diwan rejected the claim that the dispute should have been settled in Saudi Arabia, holding that in the case at hand, other foreign laws were also applicable, besides Saudi law. Moreover, when the US party insisted on enforcement of its entitlements under the arbitration clause, the Diwan asked the parties to refer the dispute to their chosen contractual forum. ${ }^{92}$

Where all the parties to the arbitration are Saudis and the dispute is subject to Saudi law, there exists no right to arbitrate outside Saudi Arabia, or on the basis of foreign laws, as this would violate Saudi public policy. In case 143/T/4 of 1412 $\mathrm{H}$ (1992), the Saudi disputants agreed to refer their dispute to arbitration in Zurich under the ICG's Rules of Procedure. Given that all the parties and the subject matter were only of Saudi concern, the arbitration clause was by implication void as being contrary to public policy. The Committee commented in its decision as follows:

\footnotetext{
90 Ministry of Justice of Saudi Arabia, available at www.moj.gov.sa/UploadedImages2/20.doc. Another striking contradiction is that whereas the Implementing Rules do not pose an obstacle to non-Saudi Muslims, the Ministry of Justice requires instead, through its website Circular, that applicants possess Saudi nationality.

91 Diwan Almazalim, Decision No. 155/T/4 of 1415 H (1995).

92 Diwan Almazalim, Decision No. 43/T/4 of 1416 H (1996).
} 
This dispute is subject to Saudi law and the arbitration clause providing for the settlement of the dispute by means of arbitration in Zurich under the rules of the ICC is null and void. Regardless of its contradiction with the Saudi law of arbitration and its Implementing Rules, this is an attempt to eliminate the jurisdiction of the Saudi judiciary over the dispute, which is against the public policy of Saudi Arabia.

The Committee decided that the arbitration clause was null and void and obliged the parties to refer the dispute to the Diwan Almazalim. ${ }^{93}$ It is evident, therefore, as regards the issue of applicable law, that where a foreign element is present in a dispute, the Saudi courts will give weight to the place of actual performance. Nonetheless, the courts will not feel inclined to apply foreign laws in every case in which such laws would otherwise be applicable, but will instead grant the parties the choice of settling their dispute before a court or through arbitration in the given jurisdiction. Where, however, both parties are Saudi nationals, Saudi law will always be the applicable law as well as the lex arbitri.

\section{ARBITRAL PROCEEDINGS: NOTIFICATIONS, REPRESENTATION AND FAILURE TO APPEAR}

In the previous sections we examined the determining role of the competent authority with regard to the compromis. The same authority enjoys, moreover, responsibilities vis-à-vis the proceedings themselves. The arbitral proceedings will be supervised by the relevant competent authority, which will appoint a clerk to act as a secretary for the arbitral tribunal. The duties of the secretary include establishing the necessary records necessary for the registration of the request for arbitration and their submission to the competent authority for approval. The clerk is also responsible for issuing the notifications ${ }^{94}$ and communications provided in the Arbitration Act and for any other duties assigned to him by the competent Minister. ${ }^{95}$ Such notifications include those pertaining to the time and place of the hearings and all communications between the tribunal and the competent authority, witnesses, experts and all other concerned individuals and entities. The arbitral tribunal is under an obligation to set hearing dates within a period not exceeding five days from the date of its notification of the decision approving the arbitration agreement and must notify the parties accordingly through the clerk of the competent authority. ${ }^{96}$ Irrespective of whether these

93 Diwan Almazalim, Decision No. 143/T/4 of 1412 H (1992).

94 Whereas generally notifications are addressed to the physical persons named as the parties to the dispute, notifications to states are to be delivered to competent Ministers, regional governors or relevant heads of government authorities, in accordance with Implementing Rules, arts. 13-15. Where the dispute relates to companies, associations and private establishments, the notifications and communications are to be delivered to the main office as set forth in the commercial register to the chairman of the board of directors, or to the general manager, or to an employee substituting for such person; and with respect to foreign companies having a branch or agent in the Kingdom, to such branch or agent. See Implementing Rules, art. 15 and Law of Procedure Before Shari'a Courts, art. 18.

95 Implementing Rules, art. 9. In accordance with Arbitration Act, art. 8, the clerk of the relevant competent authority will be in charge of all notifications and notices related to the arbitration proceedings.

96 Implementing Rules, art. 10. 
notifications are carried out at the request of any of the parties or by an order of the arbitrators, the clerk should be assisted by the police and the local authority within the scope of their area of competence. ${ }^{97}$ Notifications and communications are to be made exclusively in Arabic, addressed to all parties and must contain all the required information. ${ }^{98}$

As regards representation, the parties should appear on the day of the hearings, either in person or through a representative pursuant to a power of attorney, or what is known in Arabic as Wakalah, issued either by a notary public, ${ }^{99}$ a designated public authority, or as certified by the Chamber of Commerce and Industry. The option of appearance through a representative does not prejudice the right of the tribunal to require the personal appearance of a party, if circumstances so require. ${ }^{100}$ The term Wakalah can be translated as proxy, but under the Shari'a the legal effects of a Wakalah are broader than a mere agreement between two persons wherein one simply acts on behalf of the other. It encompasses, in cases of unconditional Wakalah, the entitlement to assume fully the rights of the principal party. In Islamic law, the Wakalah is a flexible, sui generis, contract because of the freedom of the parties to dissolve it. It is dissolved, inter alia, by the death of the agent or the principal, regardless of each party's knowledge as to the death of the other. It may also be dissolved by resignation, recession, or any other ground relating to the dissolution of contracts. In the case of a conditional Wakalah, the contract terminates at the time of its execution. Where doubt persists, the power of attorney terminates on the day the final award is rendered. ${ }^{101}$ It is required that the agent be qualified to accept a power of attorney, according to law of Saudi Arabia. ${ }^{102}$

If one of the parties fails to appear before the arbitral tribunal and the tribunal is satisfied that said party was notified personally, it may decide the dispute in that party's absence if the parties have deposited in the arbitration file a memorial of their claims, defences, answers and supporting documents. ${ }^{103}$ The award in such cases shall be deemed as if all parties were present. Where a party was not duly summoned, the proceedings will be postponed. If there is more than one defendant party and one of these was not duly summoned and all the defendants fail to appear, or the party not duly summoned fails to appear, the tribunal will, save under urgent circumstances, adjourn its hearings to a later date. In the

\footnotetext{
97 Implementing Rules, art. 11 and Law of Procedure Before Shari'a Courts, art. 15 determine that only the Umdah (otherwise known as the chief of the quarter), the police, head of the 'centre', or the chief of the tribe can deliver communications and notifications.

98 See Implementing Rules, art. 12.

99 The body responsible for issuing powers of attorney in Saudi Arabia is known as ketabat alad'l and corresponds with the office of Notary Public.

100 Implementing Rules, art. 17.

101 M. Alatasi, Sharh Almjallah [Commentary of the Commercial Code of the Ottoman Empire] (Maktabah Haqqaniyah Publishers, 1949), vol. 5, arts. 1521-1530.

102 Persons who are unable to act as agents or accept the power of attorney before Saudi judicial bodies include minors, women and non-Saudis. See Code of Law Practice of Saudi Arabia, Royal Decree No. M/38 of 28/ 06/1422 H (2001), reprinted in Umm Alqura Gazette, No. 3867 of 17/08/1422 H (2001).

103 Implementing Rules, art. 18.
} 
absence of any failure to notify, the award will be deemed made as if all parties were present. The same is true where a party or his representative makes an appearance at any hearing or submits a defence memorial, or a related document. If a defaulting party makes an appearance before the end of the hearings, the tribunal is obliged to reschedule the hearings anew, because the defaulting party can no longer be considered duly notified and absent. Therefore, any award issued without rescheduling the hearings anew will be null and void. There are strict conditions attached to the issuance of a judgment in absentia under Hanbali teachings. Article 18 of the Implementing Rules succinctly codifies the exceptional cases where the tribunal can render an award without the physical presence of the parties to the dispute. Under Hanbali teachings, an award rendered in absentia requires a judicial confirmation before its execution because the defendant may have a defence against the claim; nonetheless, as a general rule, the tribunal is not allowed to issue a judgment in absentia except as mentioned above. ${ }^{104}$ The same applies mutatis mutantis in cases of renotification. ${ }^{105}$

\section{(a) Conduct of Proceedings}

Under traditional Islamic practice, disputes were settled in public places. The judge or governor of a region sat in the mosque or his Diwan to hear and settle disputes. This tradition is reflected in article 20 of the Implementing Rules, according to which all cases must be publicly heard before arbitral tribunals, unless said tribunals decide otherwise, either at their own initiative or following a request by one of the parties. Accordingly, any member of the public is allowed to attend the hearings without restriction. ${ }^{106}$ Where the arbitral tribunal decides to privatise the hearings, it cannot extend this option to the rendering of the final award, which must always be made in public. ${ }^{107}$ This provision is evidently in conflict with one of the fundamental tenets and purposes of arbitration, which is confidentiality, which itself is considered one of the principal advantages of arbitration over litigation. ${ }^{108}$ We have already stated that Saudi law does not view arbitral and regular court proceedings as being fundamentally different in legal nature. Some commentators claim that the objective behind the public nature of arbitral proceedings is to enhance transparency and impartiality. This position, however, is in stark contrast to current Saudi on-the-ground practice. As a general rule, Saudi court proceedings are held in public. In reality, however, persons not involved in the dispute cannot even enter the courtroom. In addition to the negative attitude of some judges to the attendance of members of the public having no direct interest in the dispute, the infrastructure of most courtrooms in

\footnotetext{
104 Ibn Qodamah, supra n. 17 at vol. 14, p. 96.

105 Implementing Rules, art. 19.

106 A. Aldar'an, Alqawa'ed Al ijrae'iyah fe Al morafa'at Alshar'iyah [Procedural Rules in Fudicial Proceedings] (Altawbah Publications, 1993), p. 67.

107 Implementing Rules, art. 20.

108 See A. Redfern and M. Hunter, Law and Practice of International Commercial Arbitration (Sweet \& Maxwell, 2004), pp. 32-39, wherein the authors furnish examples, however, demonstrating that complete confidentiality is not an absolute rule in international arbitral practice.
} 
Saudi Arabia does not physically enable members of the public to attend court proceedings and the law is clearly out of touch with reality by imposing publicity upon arbitral proceedings when the public courts themselves do not apply the same principle to their own proceedings. Article 20 of the Implementing Rules is also supported by article 61 of the Law of Procedure Before Shari'a Courts, which states that the judge on his own initiative, or at the request of one of the litigants, can close hearings to the public in order to maintain order, observe public morality, or protect family privacy. 109 Although this provision does not contradict the Hanbali law of arbitration, its contemporary application is at odds with the internationally accepted private nature of arbitration.

As a general rule, the arbitral tribunal is not allowed to decide the dispute without hearing all the parties and giving them an equal chance to present their evidence. ${ }^{110}$ Moreover, reliance on the arbitrator's personal knowledge, without any further corroborating evidence, is inadmissible because the suspicion of bias may constitute a valid ground for challenging the award.111 The typical procedure before a Saudi court or arbitral tribunal consists of three stages. First, the plaintiff raises his claim, which must be precise and detailed. The claim itself may be presented in writing or orally on the day of the hearing. At the second stage the arbitrator invites the defendant to answer the plaintiff's claim, whereby the defendant may either admit the claim (iqrar) or deny it (nokoul). If the defendant denies the claim, the arbitrator will ask the plaintiff to adduce evidence (baiyenah), which will take the form of oral testimony. At the final stage, where the plaintiff fails to provide the tribunal with testimonial evidence, the arbitrator will administer oath (yameen or qasam). If the defendant swears that the claim is groundless, the claim will be dismissed if there is no further proof adduced by the plaintiff; however, if the defendant refuses to take the oath, the case will be decided in favour of the plaintiff. 112

In general terms, the chairman of an arbitral tribunal has the same duties and powers as a regular court judge. ${ }^{113}$ The main difference between arbitration and litigation is the arbitrators' lack of enforcement power. Therefore, where arbitral tribunals are faced with issues that do not fall within their competence, such as forgery or corruption, the matter must be referred to the competent judicial or executive body. Under such circumstances, arbitral proceedings are suspended until such time as the crucial matter is resolved and a final and irrevocable resolution, whether through judgment or otherwise, has been rendered by the competent authority. ${ }^{114}$ As a result, there is no right of imprisonment for

\footnotetext{
109 Law of Procedure Before Shari'a Courts, art. 61. Royal Decree No. M/21 of 20/05/1421 H (2000), reprinted in Umm Alqura Gazette, No. 3811 of 17/06/1421 H (2000).

110 Implementing Rules, art. 22. See also, Ibn Qodamah, supra n. 17 at vol. 14, p. 96.

111 Ibid.

112 See in general, Ibn Farhoun, Tabsirat Alhokkam Fe Usul Alaqdiyah Wa Manahej Alahkam [fudges' Guide] (revised and reprinted by T.A. Sa'ad, Maktabat Alkolliyat Alazhariyah Publishers, 1986).

113 Under Implementing Rules, art. 39, arbitrators are not bound by regulatory procedures, other than relevant Saudi legislation.

114 Implementing Rules, art. 37.
} 
misbehaviour before the tribunal. In case of misbehaviour, the chairman can only expel the person from the place of the hearing and report him to the competent authority. Shari'a judges, on the other hand, have the power to imprison. ${ }^{115}$ Each arbitrator has the right to direct questions and interrogate parties or witnesses through the chairman of the tribunal. ${ }^{116}$ Arbitral judges possess discretionary power to postpone a hearing where the parties so request in order to better prepare their cases. ${ }^{117}$ Although not even Diwan decisions constitute legally binding precedent, in accordance with article 28 of the Implementing Rules, the parties may be asked by the tribunal to present any material that has probative value for the settlement of the dispute. ${ }^{118}$ The Diwan has clarified that this may include foreign arbitral awards as precedent, provided they do not violate the Shari'a and Saudi public policy. ${ }^{119}$ The arbitrator may order an investigation of the facts if these are relevant, admissible and material to the dispute, as well as depart from normal evidentiary procedure if he sees fit and provides justification. ${ }^{120}$ Witness statements are admissible only if they are in conformity with the Shari'a, the witnesses themselves have reached the age of puberty, are not subject to any incapacity and are trustworthy. Non-Muslim witness testimony is admissible in all fields, except in relation to hodoud. The Shari'a requires a through investigation of witness trustworthiness because if there is any doubt, such testimony is inadmissible. Oral testimony is provided on-the-spot before the chairman at the request of one of the parties. Witnesses may be disqualified for reasons other than untrustworthiness, on the same grounds that a person may not be qualified to assume the role of an arbitrator. ${ }^{121}$ Experts are treated and considered as witnesses for all legal purposes and can be challenged on the same grounds as witnesses and arbitrators. ${ }^{122}$

Arabic is the official and only language applicable to arbitration proceedings. ${ }^{123}$ This is true irrespective of whether the proceedings are at a written or oral phase. This language restriction is imposed upon all persons participating in the arbitral proceedings. Foreigners not versed in Arabic must be accompanied by an accredited translator who co-signs that part of the record of the hearing which was translated. Equally, given that Arabic is the official language in Saudi Arabia, all communications with and contracts entered into with Saudi governmental entities must be in Arabic. Although foreign parties may enter into contracts with the Saudi government in which an additional language is employed, where a dispute relating to the execution of the contract

\footnotetext{
115 Law of Procedure Before Shari'a Courts, arts. 69 and 70.

116 Implementing Rules, art. 23.

117 Ibid. art. 26. See also, Law of Procedure Before Shari'a Courts, art. 65.

118 Supplementary expert witness statements are not binding upon the tribunal under Implementing Rules, art. 34, and cannot even be classified as evidence under Hanbali teachings. See Ibn Qodamah, supra n. 17 at vol. 14, p. 262.

119 Diwan Almazalim, Decision No. 29/T/4 of 1413 H (1993).

120 See Implementing Rules, arts. 29 and 30.

121 Ibn Qodamah, supra n. 17 at vol. 14, p. 262.

122 Implementing Rules, art. 33.

123 Ibid. art. 25.
} 
arises, it is only the Arabic text that is considered authoritative. ${ }^{124}$ This principle was established through article 1 of the Basic Law ${ }^{125}$ and was also supported by article 1 of the Law of Procedure Before Shari'a Courts, which states that Arabic is the official language for all hearings and communications and if a circumstance requires the use of another language, the relevant document or hearing should be translated into Arabic. ${ }^{126}$ In Hanbali teachings, if one of the parties to the dispute does not speak Arabic and the arbitrator is not familiar with that party's language, an accredited translator must attend the hearing to assist in the proceedings. The translators should possess the characteristics of an adalah, or full legal capacity. ${ }^{127}$ Where the parties reach an extra-judicial settlement to their dispute, they can request the tribunal at any stage of the proceedings to record their agreement, whether this is an admission, settlement, or waiver, and the tribunal will make an award based on the parties' agreement. ${ }^{128}$

\section{CHALLENGING AND ENFORGING ARBITRAL AWARDS}

Although the arbitral tribunal may not, during the review of the case and deliberation, hear explanations of one of the parties without the presence of the other party, nor receive memorials or documents unless the other party examines the same, it may exceptionally consider new documents if it deems them material and of probative value. If it does so, it may extend the date for pronouncing the award and reopen the proceedings by an intermediate award or interlocutory decision in which its reasons and justifications are duly recorded and the parties notified of the supplementary hearing dates. ${ }^{129}$

All arbitral awards should be adopted by majority (except in cases of sole arbitrators) and should contain all the information for which the dispute was referred to arbitration. ${ }^{130}$ Where unanimity has proven impossible, four methods are supported under Islamic law and practice in order to bring such a result about. First, when forming the arbitration agreement, the parties should insert an odd number of arbitrators. Secondly, where the parties initially decided on an even number of arbitrators and no unanimity was reached, they should seek the assistance of an external arbitrator who will decide the case according to his opinion. The external arbitrator is not allowed to come up with a new opinion; his job is to choose one of the available decisions only. ${ }^{131}$ Thirdly, if the arbitrators fail to issue the award, the dispute can be decided by another tribunal or by a sole

124 See e.g., Gas Concession Agreement between the Kingdom of Saudi Arabia and Lukoil Overseas, arts. 9-31, reprinted in Umm Alqura Gazette, No. 3990 of 15/03/1425 H (4/05/2004).

125 Basic Law of Saudi Arabia, Alnezam Alasasi Lelhokm. Royal Decree No. (90/A) of 28/06/1412 H (1992).

126 See Law of Procedure Before Shari'a Courts, art. 1.

127 Ibn Qodamah, supra n. 17 at vol. 14 p. 84.

128 Implementing Rules, art. 24. The same is true with regard to Shari'a courts, according to Law of Procedure Before Shari'a Courts, art. 76.

129 Implementing Rules, art. 40 and Law of Procedure Before Shari'a Courts, arts. 66, 159-160.

130 Implementing Rules, art. 41.

131 Al-Kenain, supra n. 9 at p. 124. 
arbitrator. ${ }^{132}$ This option may inconveniently prolong the dispute, which is contrary to the supposed speedy nature of arbitration. Fourthly, where unanimity was not reached even though the parties exhausted the above-mentioned methods, they can refer their dispute to litigation as a last resort. ${ }^{133}$ In practice, if the arbitral tribunal fails to issue its decision within 90 days from the date of approval of the arbitration agreement by the supervisory authority, the case will be referred to the Diwan, which will either act as an external arbitrator and choose one of the available opinions, decide the case anew, or grant the arbitral tribunal a time extension. 134

When making the award, the arbitral tribunal should not act ultra vires by exceeding its terms of reference and examine issues not encompassed in the arbitration agreement. In case $33 / \mathrm{T} / 4$ of $1414 \mathrm{H}$ (1994), the arbitration agreement required the tribunal to determine the amount of damages for the late performance of a contract. The arbitral tribunal thought it prudent to additionally determine in the same award the initial cost of the contract. The determination of this additional matter was rejected by the Diwan on the ground of exceeding the terms of the arbitration agreement. ${ }^{135}$

The arbitral tribunal is responsible for correcting technical, typographic and mathematical errors. ${ }^{136}$ It is also obliged to issue a supplementary award to explain possible ambiguities and uncertainties in the text of the arbitral award, which can only be issued following a request from the parties. ${ }^{137}$ Where the parties fail to prevail over all of their claims, an award may be made apportioning the fees between them according to the determination of the supervisory authority or allocating the entirety of the fees against only one of the parties. ${ }^{138}$ Any party may object to an order assessing the arbitrators' fees to the authority. The judgment of the competent authority is final. 139

The arbitral award becomes an enforceable instrument upon the issuance of the enforcement order, which is the responsibility of the supervisory authority. ${ }^{140}$ The supervisory authority must dispatch to the winning party the enforcement copy of the arbitral award, which ends with the following statement: 'All government departments and agencies concerned are hereby requested to execute this judgment by all available legal means even if it may require the use of coercive force by the police'. ${ }^{141}$ The supervisory authority cannot issue the enforcement order unless requested to do so by the winning party or third parties having an interest in the enforcement of the arbitral award. The enforcement request from third parties should be submitted to and accepted by the Diwan,

\footnotetext{
132 Ibn Qodamah, supra n. 17 at vol. 10, p. 546.

133 Ibid.

134 Diwan Almazalim, Decision No. 35/T/4 of 1418 H (1998).

135 Diwan Almazalim, Decision No. 33/T/4 of 1414 H (1994).

136 Implementing Rules, art. 42.

137 Ibid. art. 43.

138 Ibid. art. 45.

139 Ibid. art. 46.

140 Ibid. art. 44.

141 Ibid. art. 44 and Law of Procedure Before Shari'a Courts, art. 196.
} 
provided that said third parties have an interest in the enforcement of the award, such as guarantors and creditors. The argument that such third parties possess no entitlement because they are not parties to the arbitration agreement has been rejected by the Diwan. ${ }^{142}$ In addition, the competent authority should ensure that the party requesting the enforcement has an interest in the enforcement of the award, subsequently review the award itself and confirm that it does not violate the public policies of the Kingdom. ${ }^{143}$

\section{(a) Public Policy in Saudi Arabia}

Public policy is of a great importance to arbitration, especially when it comes to the enforcement of an arbitral award, irrespective of whether this is a domestic or a foreign award. As a general rule, an arbitral award is unenforceable if it violates the public policy of the country where enforcement is sought. ${ }^{144}$ This is also true in Saudi Arabia and is applicable to both foreign and domestic arbitral awards, despite the fact that the latter proceedings have by the time of enforcement already been very closely monitored by the supervisory authority. As a result, refusals to enforce are more common when setting aside foreign arbitral awards, because public policy in Saudi Arabia covers a vast area of practice that might be unknown to foreign arbitrators sitting abroad and applying non-Saudi lex arbitri. The following section aims to provide an overview of Saudi public policy, its sources and how it is applied in practice.

Public policy in the Saudi Kingdom is derived from three principal sources: (a) the Shari'a; (b) Royal power which itself is drawn from the Shari'a with an emphasis on public customs and public interest within the framework of the Shari'a's prescriptions; and (c) public morals. At the outset it should be noted that, historically, a distinction has been drawn by Muslim scholars between Shari'a and Islamic jurisprudence, or what is known in Arabic as figh. The concept of Islamic law was not in use at the time of the Muslim classical scholars and began to develop as a reaction to Western influence. The concept of Shari'a is broader than jurisprudence and the jurisprudence itself comes within (as do other concepts of Islam, such as Islamic creed and Quranic sciences) the umbrella of Shari'a. ${ }^{145}$ Shari'a or Ash-Shari'a literally means the pathway or a way to be followed and the way that a Muslim has to walk in life. In its original usage, the term Shari'a meant the road to the watering place or path leading to the water, i.e. the way to the source of life. ${ }^{146}$ From the latter point of view, Arab lexicographers have treated the term and developed it to mean 'the law of water' and in time it was extended to cover all aspects of Muslim life, both spiritual and that pertaining to the

\footnotetext{
142 Diwan Almazalim, Decision No. 136/T/4 of 1409 H (1989).

143 Albejad, supra n. 18 at p. 240.

144 See 1958 New York Convention on the Recognition and Enforcement of Foreign Arbitral Awards, art. 5, 330 UNTS 538.

145 I. Abdal-Haqq, 'Islamic Law: an Overview of its Origin and Elements' in (2002) 7 J Islamic Law and Culture 27 at pp. 26-31.

146 Ibid.
} 
exigencies of everyday life. ${ }^{147}$ Shari'a is best translated as the 'way of life' and Ash-Shari'a as the 'way of the Muslim life', which is wider than the mere formal rites and legal provisions. Islamic law may be defined as the entire system of law and jurisprudence associated with the religion of Islam.

The primary sources of Shari'a are the Qur'an and the Sunnah and there exists a closed number of other secondary sources or methods for adducing appropriate normative behaviour in response to new incidents and unregulated circumstances. These secondary sources are Ijma', Ijtihad, Qiyas, public interest, custom, or what is known in Arabic as Urf. The methods of Ijma', Ijtihad and Qiyas are employed in the light of current circumstances in order to shed light onto and analyse the Quran and the Sunnah. The sustained use of these secondary sources led to the creation of a body of law known as figh. ${ }^{148}$ Western scholars tend to use the terms Shari' $a$, and Islamic jurisprudence as 'fiqh', interchangeably. The afore-mentioned distinction between the two should become clear and receive scholarly attention, given that Shari'a is the foundation of all doctrines formulated and developed under figh, whereas the figh represents a human understanding and analysis of Shari'a sources. ${ }^{149}$ The term 'Saudi law' is more comprehensive than Shari'a and encompasses Islamic law and the Codes and Regulations adapted from other laws within the general framework of Shari'a principles. There are a few exceptions to this rule, particularly as regards Saudi legislation that is unrelated to Islamic teachings and principles, such as the Banking Control Law, because it regulates some activities that are clearly prohibited under Islamic law.

In Saudi Arabia, the Shari'a's primary sources, the Qur'an and the Sunna, have supremacy over all laws and man-made regulations or normative instruments. In the 1920s, King Abdul-Aziz attempted to codify the teachings of the four Islamic schools in a manner similar to that by which the Majalla codified Hanafi fiqh. Despite his best efforts, this project was vociferously opposed by certain radical scholars and did not materialise. In combination with his codification project, the King ordered Shari'a judges not to be bound by the rules of one school of fiqh, with the aim that the prevalence of one school should not have the result of abrogating another. ${ }^{150}$ At the same time, however, some Ulamas had their own agenda; they not only opposed the King's reform plans, but, moreover, sought to exert pressure on judges in all Saudi courts with a view to applying exclusively Hanbali figh under the teachings of the late Scholar Ibn Taymiyyah. The main reason for their opposition rested in their fear that the expansion of civil codes

147 C. Mallat, 'From Islamic to Middle Eastern Law: a Restatement of the Field (Part 1)' in (2003) 51 Am. $\mathcal{J}$ Comp. L 699. See Quran, verses 45:18 and 5:48.

148 The Quran is the sacred book of Islam, believed by Muslims to be the infallible word of God dictated to Prophet Muhammad; the Sunnah is a collection of the sayings of Prophet Muhammad, examples of his behaviour, things he approved and things he condemned during his lifetime. Ijma' is the consensus of qualified Islamic scholars of a given generation on particular points of Islamic law. Ijtihad translates from Arabic as 'human activity' and refers in legal parlance to the endeavour of a scholar to derive law on the basis of evidence found in the Shari'a texts. Qivas constitute a process of analogical reasoning from a known injunction to a new injunction.

149 Abdal-Haqq, supra n. 145 at pp. 26-31.

150 Sfeir, supra n. 35 at pp. $729-744$. 
could eventually culminate at the expense of the Shari'a and ultimately lead to the promulgation of secular laws that have little or no connection with Shari'a. In practice, although the Saudi legal system is premised on Shari'a on the basis of Hanbali teachings, judges have the freedom to apply any of the four schools of figh. ${ }^{151}$ This judicial latitude granted to Saudi judges is the direct result of the afore-mentioned order of King Abdul-Aziz to Shari'a judges. ${ }^{52}$ Saudi judges currently rely on a number of legal commentaries (authored by recognised Islamic legal scholars) in the delivery of their judgments, but it should be noted that a codification of these dispersed commentaries is expected in the foreseeable future. Apart from Ibn Qudamah, the majority of scholars who authored these commentaries follow the teachings of the Hanbali scholar Ibn Taymiyyah. ${ }^{153}$

According to article 7 of the Saudi Basic Law, the ruling regime derives its power from the Holy Qur'an and the Prophet's Sunnah, which have supremacy over all state laws. ${ }^{154}$ Accordingly, the imposition of public policy restrictions within the Kingdom cannot be relied upon to violate Shari'a principles under any circumstances. The Basic Law even emphasises that even a temporary state of emergency during turmoil cannot violate article 7, which renders the Shari'a the only source of regulation in the Kingdom. ${ }^{155}$

Just like Saudi law, the Kingdom itself as a political entity is inseparable from religion. ${ }^{156}$ Regardless of his considerable regulatory authority, the King lacks the power to legislate in the very extensive field which has already been regulated by the Shari'a, in respect of which he is bound by the same duty of obedience as are all of his subjects. ${ }^{157}$ Consequently, it can be said that the separation of law from religion is impossible in most aspects affecting public life in Saudi Arabia. Given the Kingdom's political structure as an absolute monarchy, the King is endowed with authority to promulgate regulations by issuing such royal decrees that supplement existing Shari'a rules with a view to adapting to new circumstances, especially in relation to trade and commerce. 'In doing so, the Government tries to balance traditional prospects against modern needs. ${ }^{\prime} 58$ Royal Decrees can also be considered a codification of some aspects of Shari'a law. This codification is achieved with the assistance of foreign laws and common practices which do not necessarily violate Shari'a principles. The decisions of judicial bodies have little impact on public policy, because in Islamic legal practice they merely offer an

151 These religious schools are called in Arabic Mathahib and consist of the Hanbali, Hanafi, Maliki and the Shafi'e.

152 Sfeir, supra n. 35 at p. 732.

153 These books are Almoghni by Ibn Qudamah; Asharh Alkabeer by Ibn Qodamah; Sharh Zad Almustaqna' by Albahouti and Alhajjawi; Sharh Montaha Al Eradat by Alfoutohi and Albahouti; and Manar Assabeel by Meri'e Alhabnali and Ibn Douawan.

154 See Saudi Basic Law, art. 7. Royal Decree No. (90/A) of 28/06/1412 H (1992).

155 Ibid. arts. 1 and 7.

156 D.J. Karl, 'Islamic Law in Saudi Arabia: What Foreign Attorneys Should Know' in (1991) 25 Geo. Wash. $\mathcal{J}$ Int'l $L$ and Econ. 131.

157 J. Schacht, 'Islamic Law in Contemporary States' in (1959) 8 Am. 7 Comp. L 133 at pp. 133-136.

158 Karl, supra n. 156 at p. 142. 
interpretation of the Shari'a and relevant Royal Decrees and are, moreover, subordinate to these.

What exactly constitutes public morals, interests and customs is not clearly delineated in Saudi law. What is abundantly precise, however, is that anything that is deemed as violating the Shari'a would certainly fall outside acceptable public policy constraints. When discussing about Saudi society in search of public morals and interests, it should be noted that the terms Deen, which means religion, and Adat, meaning custom, have been used interchangeably. The reason for this lies in the fact that most customs and traditions have either been derived from religion or upheld by it. This observation, however, may produce the result of restricting the enforcement of foreign arbitral awards in cases where the outcome of an arbitral award is contrary to Saudi public customs. The determination of the concept of public interest under Shari'a is derived through the use of the method of istihsan. The term istihsan may be translated as 'juristic preference'. ${ }^{159}$ Another scholar preferred to translate it as 'public interest'. Conceptually, istihsan may be defined as the process of selecting one acceptable alternative over another, on the ground that the first appears more suitable for the situation at hand, even though the selected solution may be technically weaker than the rejected one. Equally, istihsan has been viewed as a process for selecting the best solution for the general public interest as a form of j̈tihad. ${ }^{160}$ Istihsan allows judges and scholars some flexibility when interpreting the law to allow for the infusion of elements deemed useful. In other words, istihsan constitutes a permit for the spirit of the law to prevail over its letter. ${ }^{161}$ Slight divergences exist between the various schools. Hanbali scholars call it istislah, which may be translated as equity or public interest, whereas Maliki scholars refer to it as Almasaleh Almursalah, which denotes a departure from strict textual adherence in favour of public welfare. ${ }^{162}$ The principal precondition for the validity of istihsan is its compliance with the principles of Shari'a. Nonetheless, there are situations where the non-application of a Shari'a rule is more beneficial for public interest than strict textual application. For instance, in the field of finance and commerce, the application of Shari'a may obfuscate socio-economic development, as is the case with so-called istisna' contracts. ${ }^{163}$ As a general rule,

${ }^{159}$ H.E. Fadel, 'The Islamic Viewpoint on New Assisted Reproductive Technology' in (2002) 30 Fordham Urban Lf 147 at pp. $148-150$.

${ }^{160} \mathrm{~J}$. Makdisi, 'Legal Logic and Equity in Islamic Law' in (1985) 33 Am. F Comp. L 63 at pp. 63-78. For a brief description of ijtihad, see supra n. 148.

161 Fadel, supra n. 159 at p. 150.

162 Makdisi, supra n. 160 at p. 73.

163 Istisna' contracts are derived originally from slam contracts, wherein one party paid a year in advance for crops of a particular weight at the time of harvest. Istisna', or sale by manufacture, is a contract to manufacture a particular good not yet in existence, for an agreed price. The buyer need not pay for the good until its acceptance and both parties may revoke their agreement at any time before delivery. See F.E. Vogel and S.L. Hayes, Islamic Law and Finance: Religion, Risk and Return (Kluwer, 1998). Some scholars distinguished between the slam and istisna' contracts, but both seem to be based on the same theory; however, the slam is used mainly in respect of crops and carries a greater risk of a future discounted price. Istisna' contracts, on the other hand, are more common in construction and manufacturing and are more flexible in that they serve as financing and hedging tools. 
the object of the contract must exist at the time when the contract becomes binding upon the parties. The requirement of the existence of the object at the moment of the conclusion of the contract was made to protect the parties from assuming any risk through hazard or uncertainty likely to harm party interests. ${ }^{164}$ Public interest, therefore, required a relaxation of strict contract rules. This was done by Prophet Muhammad himself when he allowed Muslims to conclude contracts with future objectives under certain circumstances, even though the general rule requires otherwise. At present, public interest is determined by reference to specific suitable options within the framework of the main principles of Shari'a.

The Kingdom maintains a negative list of activities excluded from foreign investment. This is a fine example of activities prohibited for the benefit of public interest. ${ }^{165}$ When it comes to the protection of public interest, Saudi authorities consider the Shari'a at first instance, as well as the will of its population. King Abdullah bin Abdul-Aziz in one of his speeches to the Shura Council underlined the fundamental tenets of Saudi policy, stating that 'we will work in the interest of the religion, homeland, our citizens and our traditions'. ${ }^{166}$

\section{CONGLUSION}

In assessing a legal system that is fundamentally different to the types of legal systems that Western lawyers are used to, one must necessarily examine the underlying reasons for such diversity. In the case of Saudi arbitration law, it is evident that two reasons are particularly prevalent. The first concerns the Kingdom's troubled post-colonisation past, during which some of the arbitral tribunals determining cases to which it was a party rejected Islamic law as the law governing its contractual relations with third parties, even though this law was clearly stipulated in the relevant contracts. The frustration and embarrassment caused as a result had an impact far greater than merely downgrading the law of a particular country under the pretext that it was undeveloped and backward. Given that Islamic law does not only pervade all aspects of normative conduct, but also all other social and public conduct within Muslim societies, those arbitral awards were perceived as having broader implications about Islam and Muslim states. Moreover, Saudi Arabia is a very conservative country in every respect, whose official policy strives to strike a balance between tradition and modernisation. ${ }^{167}$

\footnotetext{
164 N. Comair-Obeid, 'Particularity of the Contract's Subject-Matter in the Laws of the Arab Middle East' in (1996) 11 Arab LQ331 at pp. 331-336.

165 Saudi Arabia General Investment Agency (SAGIA), Negative List: Activities Excluded from Foreign Investment, available at www.sagia.gov.sa/en/business-environment/investment-laws/negative-list.html

166 King Abdullah bin Abdul-Aziz, speech to the Shura Council in Riyadh, 14 April 2007.

167 'Some countries have sacrificed the soul of their culture in order to acquire the tools of Western technology. We want the tools but not at the price of annihilating our religion and cultural values.' Statement made by Bakr Abdullah Bakr, the Head of King Fahd University of Petroleum and Minerals, cited by W. Ochsenwald, 'Saudi Arabia and the Islamic Revival' in (1981) 13 Int'l 7 Middle East Studies 271 at pp. $271-272$.
} 
The result in the Kingdom's contemporary arbitral law and judicial practice is hardly surprising. Disputes conducted in Saudi Arabia, or containing Saudi elements, are governed by the Kingdom's lex arbitri, which requires that not only the arbitration clause and compromis be submitted to a designated competent authority for approval, but that the proceedings be supervised by said competent authority throughout their duration, save where conflict of laws rules permit the parties to refer to a foreign jurisdiction. Western lawyers may at first glance find these restrictions as unduly compromising the benefits of arbitration, but closer examination reveals that equivalent procedures exist in developed arbitral fora. For one thing, both in Europe and North America the arbitration clause may be subject to scrutiny, either by the tribunal itself, or by reference to the courts of the lex arbitri. Equally, the parties are not generally free to turn to the civil courts during the course of the arbitral proceedings; institutional arbitration is to some degree monitored by the relevant institutions; and, where significant improprieties occur, whether in terms of corruption or other, the parties may approach the courts of the lex arbitri. Finally, some Western arbitral legislation provides that the award requires ratification by the courts before enforcement proceedings can be undertaken. ${ }^{168}$ Moreover, as with Western public policy that is dictated by reference to local laws and perhaps social customs, so it is with Saudi Arabia that the Shari'a is the benchmark in respect of public policy. Under this light, Saudi arbitration law does not seem to differ much from its Western contemporaries. Why, then, is it deemed problematic? The primary reason is obvious; where a Saudi element is involved, the parties cannot escape been subjected to Saudi lex arbitri. They could, of course, arbitrate outside the Kingdom and avoid all the relevant problems, but their award would subsequently be unenforceable in Saudi Arabia. Furthermore, although in most countries there exists a consistent judicial practice that embraces the supervisory authority of civil courts over arbitral proceedings, in Saudi Arabia the situation is problematic. Despite the fact that the Saudi competent authorities (particularly the Diwan) do offer some jurisprudence as to their reasoning for either accepting or rejecting arbitration clauses (and the validity of the proceedings and compliance with public policy), there is no sense of precedent. ${ }^{169}$ The judges decide on the basis of their personal opinions and are not obliged to adhere to any precedent, even if a decision of the Review Committee of the Diwan exists on a particular matter. Moreover, these cases are not generally accessible and it is telling that this is the first instance in which a compilation has been made with a view to their examination. As a result, arbitration remains a very speculative business, since the parties and their lawyers navigate through legal uncertainty. From an international law point of view, it may be argued that the decisions of all competent authorities are an expression of state practice on the basis that they are organs of the state. Thus, even if their decisions carry no binding precedent within the Saudi legal

\footnotetext{
168 See Redfern and Hunter, supra n. 108 at chs 9 and 10.

169 Nonetheless, as we have demonstrated, the Diwan is not opposed to the parties themselves introducing foreign judgments, or arbitral awards, as evidence backing up their particular claims.
} 
system, at least said decisions reflect the will of the Kingdom and bind it in its international relations. In any event, there is no doubt that a Hanbali arbitration law does exist, which itself informs Saudi arbitral law. Our analysis has demonstrated that this Hanbali corpus of law is in fact more flexible than Saudi law, particularly on the ground of interpretative techniques. This finding should dismiss the notion that Hanbalism is an archaic and backward-looking institution.

Parties intending to draft arbitration clauses and undertake arbitral proceedings in Saudi Arabia, or elsewhere in cases where a Saudi element is involved, should ensure that they are fully compliant with Shari'a law and Saudi public policy. Given the requirements regarding the status of arbitrators, foreign lawyers dealing with such disputes must constantly be alert as to reliable arbitrators that fulfil these exact criteria. 